\title{
Rural tourism: a risk factor for schistosomiasis transmission in Brazil
}

\author{
Martin Johannes Enk ${ }^{1 /+}$, Graciela Larissa Amaral ${ }^{2}$, Matheus Fernandes Costa e Silva ${ }^{3,4}$, \\ Denise Silveira-Lemos ${ }^{3,4}$, Andréa Teixeira-Carvalho ${ }^{3,4}$, Olindo Assis Martins-Filho ${ }^{4}$, \\ Rodrigo Correa-Oliveira ${ }^{3}$, Giovanni Gazinnelli ${ }^{3}$, Paulo Marcos Zech Coelho' ${ }^{1}$, Cristiano Lara Massara ${ }^{2}$
}

${ }^{1}$ Laboratório de Esquistossomose ${ }^{2}$ Laboratório de Helmintologia e Malacologia Médica ${ }^{3}$ Laboratório de Imunologia Celular e Molecular ${ }^{4}$ Laboratório de Biomarcadores de Diagnóstico e Monitoração, Instituto de Pesquisas René Rachou-Fiocruz, Av. Augusto de Lima 1715, 30190-002 Belo Horizonte, MG, Brasil

This paper reports an outbreak of acute schistosomiasis among 38 tourists who rented a country house in the district of Igarapé, the metropolitan region of Belo Horizonte, Brazil, during a holiday period in 2006. A total number of 32 individuals were positive for Schistosoma mansoni. Results of stool examinations revealed individual $\mathrm{S}$. mansoni egg counts per gram of faeces (epg) ranging from 4-768 epg with a geometric mean egg count of 45. The most frequent clinical symptoms were abdominal pain (78.1\%), headache (75\%), fever (65.6\%), dry cough (65.2\%) and both diarrhoea and asthenia (59.4\%). A malacological survey of the area, where 22 specimens of Biomphalaria glabrata were collected, revealed three (13.6\%) specimens eliminating Schistosoma cercariae. This investigation re-confirms a recently described pattern of schistosomiasis infection, resulting in the acute form of the disease and connected to rural tourism, which contributes to the spread of the disease among the middle-class and into non-endemic areas. The lack of specific knowledge about acute schistosomiasis among health services causes an increased number of unnecessary diagnostic procedures and delays in accurate diagnosis and treatment, resulting in considerable discomfort for the patients.

Key words: Schistosoma mansoni - acute schistosomiasis - rural tourism - epidemiology - diagnosis

Schistosomiasis mansoni is one of the most important endemic diseases in Brazil and is believed to mostly affect low-income populations. The disease is prevalent in 519 of the 853 municipalities in the state of Minas Gerais (MG), with an estimated number of $1,000,000$ infected people in an area of $300,000 \mathrm{~km}^{2}$ (Katz 1998). Of note, Katz and Peixoto (2000), Coura and Amaral (2004) and Amaral et al. (2006) have remarked that decreased morbidity caused by schistosomiasis is due to the availability of large-scale chemotherapy combined with a decreased prevalence of the disease and, paradoxically, with territorial expansion.

The rural tourism industry has become a new source of income for many families in the countryside and in the metropolitan regions of Brazil (Ferreira 2008). In essence, these types of activities have transformed many rural properties, which were previously involved in agricultural activities, into leisure resorts, which depend on the tourists who rent them during weekends or holidays. Furthermore, the increasing interest in rural properties for leisure and recreation purposes by the middle and upper classes of nearby population centres have raised the value of these rural properties, resulting in the elimination of these small agricultural

Financial support: FAPEMIG, CPqRR

+ Corresponding author: marenk@cpqrr.fiocruz.br

Received 12 December 2008

Accepted 8 October 2009 producers. Unfortunately, such leisure areas lack basic sanitation infrastructure, which negatively impacts the environment, resulting in pollution and contamination with infective agents. Hence, the transmission of schistosomiasis and other diseases associated with a lack of basic sanitation are favoured and new patterns of dissemination can be observed. Both social and geographic dissemination patterns occur as the disease affects high-income populations and as visitors to these water collection sites establish new schistosomiasis foci in non-endemic areas, respectively.

Together with the development of the tourism business and a lack of basic sanitation infrastructure, schistosomiasis cases have been frequently recorded in several Brazilian regions (Barbosa et al. 2000, 2001a, b, de Jesus et al. 2002, Tomé et al. 2003, Enk et al. 2003, 2004, Massara et al. 2008). Many of the tourists, who have never been exposed to the disease, can develop its acute form. Unfortunately, most of these clinical cases are not recorded at local health units, since patients reside and look for medical advice in urban centres of origin. On the other hand, acute schistosomiasis is, in many cases, a self-limiting disease and therefore passes unnoticed by health services.

The present paper is aimed to assess a $S$. mansoni outbreak in the metropolitan region of Belo Horizonte, MG, Brazil that occurred in the context of rural tourism.

\section{PATIENTS, MATERIALS AND METHODS}

Patients - A group of 42 people living in the Jardim Industrial area of Belo Horizonte rented a country house during the 2006 carnival holidays. The group, comprising 25 women and 17 men, ranged between 1-65 years 
old with mean and median ages of 22.4 and 21.5 years, respectively, belonged to the same family. Of the 42 patients, four refused to participate, resulting in 38 patients being included in this study.

Local features - The country house is located in the city of Igarapé, a metropolitan region of Belo Horizonte, approximately $30 \mathrm{~km}$ from the capital's centre. The house is constantly rented for leisure activities on weekends and holidays and, among other facilities, has a natural swimming pool supplied by a local brook (Fig. 1). Some of the brook water runs into the showers (Fig. 2) and then into a pond in front of the house (Fig. 3). The country house lacks a proper sewage disposal system.

Malacological survey - A specialised team from the René Rachou Research Institute-Fiocruz, Belo Horizonte, visited the area two months after being informed about the outbreak, in order to identify possible foci of contamination and to carry out a systematic collection of water snails in the area surrounding the country house. The collected molluscs were sent alive to the Laboratory of Helminthiasis and Medical Malacology

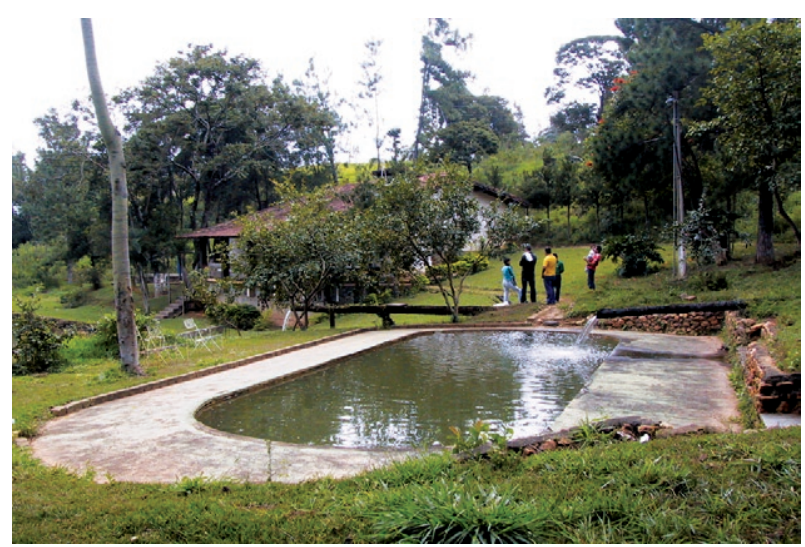

Fig. 1: general view of the site and the swimming pool supplied with natural water.

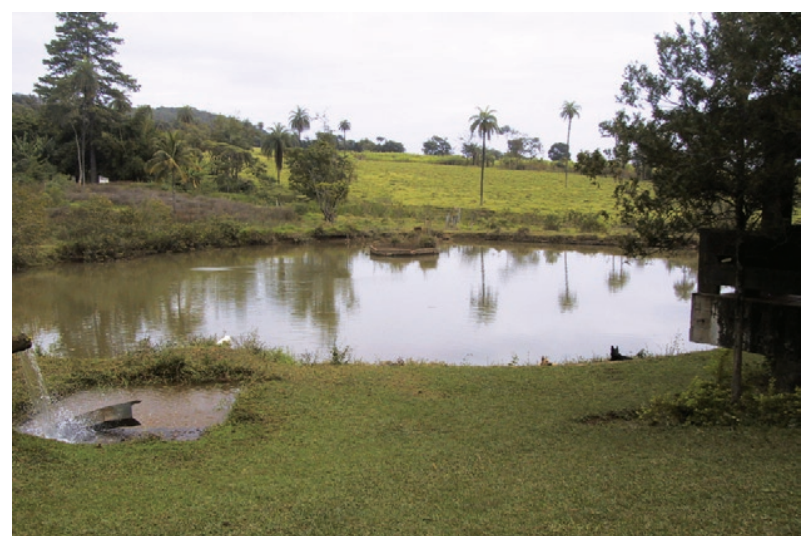

Fig. 2: open canal connecting natural water reservoirs. for both morphological (Paraense 1975) and molecular (Vidigal et al. 1998) identification. Further analysis included a search for $S$. mansoni infection, which was carried out by exposure to artificial light to induce cercariae elimination and examination under light microscopy after the molluscs were crushed.

Parasitological examination - After the research team's physician gathered an anamnesis for all participants in the study, coproscopical analysis of a stool sample from each participant was carried out. Six slides per patient were analysed according to the Kato-Katz method (Katz et al. 1972).

All participants who accepted voluntarily participation in this study signed an informed consent waiver prior to their evaluation. This study was approved by the Ethical Committee of the Fundação Oswaldo Cruz, Ministry of Health, Brazil.

\section{RESULTS}

Malacological survey - A total number of 25 water snails were collected, of which 22 were identified as Biomphalaria glabrata and three as Lymnae. Three (13.6\%) of the B. glabrata snails eliminated S. mansoni cercariae. Two of these specimens were collected from the water channel supplying the swimming pool and the other from the water channel supplying the shower (Fig. 3).

Parasitological diagnosis - Of the 38 patients who declared having contact with water in the country house, $32(84.2 \%)$ showed $S$. mansoni eggs in faeces, while six (15.8\%) were negative for S. mansoni infection. Sixteen of the positive patients were diagnosed and treated by a professional from another institution (confirmed by their medical records) and the remaining 16 , who were diagnosed at our institution, showed individual egg counts per gram of faeces (epg) ranging from 4-768, with a geometric mean of 45 epg. The remaining six participants $(15.8 \%)$ showed negative stool examinations for schistosomiasis (Table). Three of the 38 patients reported previously having an $S$. mansoni infection and undergoing treatment in the past. Of these, two showed $S$. mansoni eggs in their faeces and did not present with any symptoms. The pre-

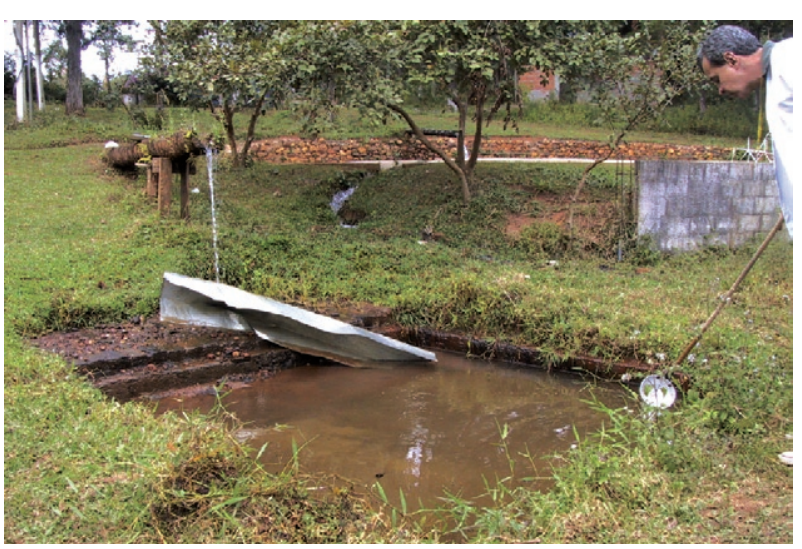

Fig. 3: pond receiving all water of the country house and its surroundings. 
TABLE

Distribution of age and gender among 42 visitors of a country house and the 32 individuals positive for Schistosoma mansoni

\begin{tabular}{|c|c|c|c|c|c|c|}
\hline \multirow[b]{2}{*}{ Age } & \multicolumn{3}{|c|}{ Individuals } & \multicolumn{3}{|c|}{ Positive individuals } \\
\hline & Male & Female & Total & Male & Female & Total \\
\hline $0-15$ & 5 & 11 & 16 & 4 & 9 & 13 \\
\hline $15-30$ & 6 & 10 & 16 & 4 & 7 & 11 \\
\hline $30-45$ & 5 & 2 & 7 & 5 & 2 & 7 \\
\hline$>45$ & 1 & 2 & 3 & 1 & 0 & 1 \\
\hline Total & 17 & 25 & 42 & 14 & 18 & 32 \\
\hline
\end{tabular}

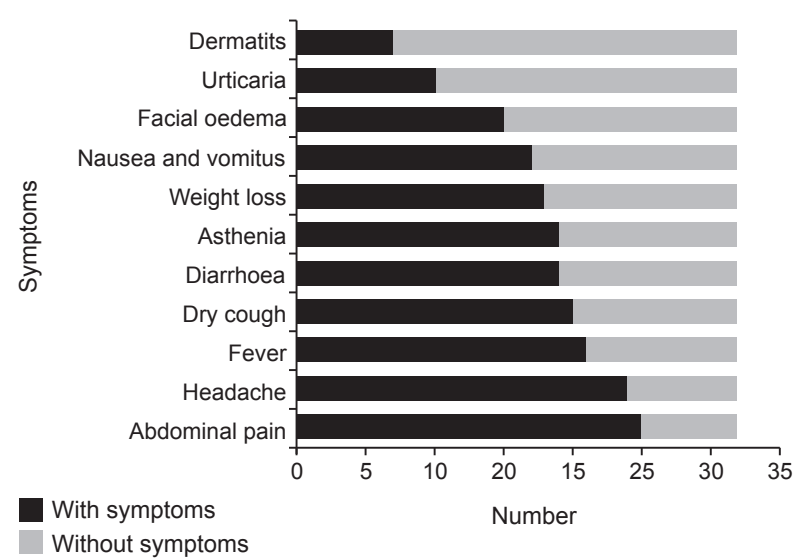

Fig. 4: distribution of symptoms among the 32 Schistosoma mansonipositive patients.

vious infections of these three participants did not take place at the location investigated in the current study.

The 16 patients diagnosed by our institution were treated, according to the recommendations of the Brazilian Ministry of Health, with a single dose of praziquantel $(50 \mathrm{mg} / \mathrm{kg})$.

Symptoms - According to the medical records and our own anamnesis of the 32 positive patients, the most frequent clinical symptoms reported were abdominal pain ( $25,78.1 \%)$, headache $(24,75 \%)$, fever $(21,65.6 \%)$, dry cough $(20,65.2 \%)$ and both diarrhoea and asthenia (19, $59.4 \%)$. Other symptoms included weight loss $(18,56.3 \%)$, vomiting $(17,53.1 \%)$, facial oedema $(15,46.9 \%)$, urticaria $(10,31.3 \%)$ and dermatitis $(7,21.9 \%)$ (Fig. 4). Three of the patients were admitted to the local hospital due to the severity of their symptoms.

\section{DISCUSSION}

The frequency of acute schistosomiasis outbreaks is increasing in Brazil. Several occurrences have been reported in the metropolitan regions of Belo Horizonte (Enk et al. 2003, 2004, Massara et al. 2008), Recife (Barbosa et al. 2000, 2001a, b) and Aracaju (de Jesus et al. 2002) and in the countryside of São Paulo (Tomé et al. 2003). The present paper confirms this observation and corroborates previous reports of increasing schistosomiasis transmission, especially in urban areas where mostly middle and upper class people, who have never been in contact with the disease, are becoming infected and suffering from the acute form of schistosomiasis.

Since the 1990s, the rural tourism business has increased in metropolitan regions (Ferreira 2008). Hotels, farms and country houses for rent, which are often located in schistosomiasis endemic areas, offer normal recreation programs as well as a wide range of adventure and ecological activities. In order to maintain the healthy, natural and untouched aspect of the environment that attracts the tourists, the leisure facilities are mostly supplied with natural water without prior treatment and, in many cases, do not have proper infra-structure for basic sanitation, which constitutes an important factor in maintaining disease transmission. In this context, infection may occur directly at the leisure facility or during adventure and ecological activities, whenever contact with natural water sources is established. This situation, which has been overlooked until now, contributes to the dissemination of the disease and to the occasional appearance of severe cases of acute schistosomiasis whenever non-immune individuals become infected.

The complex association among geographical, biological, socio-economical and medical conditions hampers the effort to accurately diagnose schistosomiasis. This, together with the fact that infected patients with unspecific symptoms seek medical advice in non-endemic areas, resulting in neither the physician nor the patient suspecting schistosomiasis, explains the numerous and sometimes unnecessary diagnostic tests ordered, as well as the retarded and often inadequate initiated treatment plan (Enk et al. 2003). In the present investigation, the professionals of the René Rachou Research Institute were informed about a possible schistosomiasis transmission by an attentive physician who was performing an abdominal ultrasound on one of the patients.

Bearing in mind that acute schistosomiasis is normally a self-limiting disease can aggravate the situation, since many cases may escape undetected. This also represents a permanent risk for the contamination of water 
snails, the intermediate host of schistosomiasis, which inhabit fresh water collections of non-endemic areas and eliminate cercariae into water, thus contributing to the establishment of disease in new areas and dissemination of schistosomiasis.

We hope that our findings will raise awareness to this increasingly common pattern of schistosomiasis transmission, which has occurred among medium-class individuals visiting endemic areas. This issue should be addressed in both the medical profession and the whole population.

\section{REFERENCES}

Amaral RS, Tauil PL, Lima DD, Engels D 2006. An analysis of the impact of the Schistosomiasis Control Programme in Brazil. Mem Inst Oswaldo Cruz 101 (Suppl. I): 79-85.

Barbosa CS, Domingues AL, Abath F, Montenegro SM, Guida U, Carneiro J, Tobosa B, Moraes CN, Spinelli V 2001a. Epidemiologia de esquistossomose aguda na praia de Porto de Galinhas, Pernambuco, Brasil. Cad Saude Publica 17: 725-728.

Barbosa CS, Montenegro SM, Abath FG, Domingues AL 2001b. Specific situations related to acute schistosomiasis in Pernambuco, Brazil. Mem Inst Oswaldo Cruz 96 (Suppl.): 169-172.

Barbosa CS, Pieri OS, da Silva CB, Barbosa FS 2000. Ecoepidemiologia da esquistossomose urbana na Ilha de Itamaracá, estado de Pernambuco. Rev Saude Publica 34: 337-341.

Coura JR, Amaral RS 2004. Epidemiological and control aspects of schistosomiasis in Brazilian endemic areas. Mem Inst Oswaldo Cruz 99 (Suppl. I): 13-19.

de Jesus AR, Silva A, Santana LB, Magalhães A, de Jesus AA, de Almeida RP, Rêgo MA, Burattini MN, Pearce EJ, Carvalho EM 2002. Clinical and immunologic evaluation of 31 patients with acute schistosomiasis mansoni. J Infect Dis 185: 98-105.
Enk MJ, Amorim A, Schall VT 2003. Acute schistosomiasis outbreak in the metropolitan area of Belo Horizonte, Minas Gerais: alert about the risk of unnoticed transmission increased by growing rural tourism. Mem Inst Oswaldo Cruz 98: 745-750.

Enk MJ, Caldeira RL, Carvalho OS, Schall VT 2004. Rural tourism as risk factor for the transmission of schistosomiasis in Minas Gerais, Brazil. Mem Inst Oswaldo Cruz 99 (Suppl. I): 105-108.

Ferreira ECS. O crescimento do turismo no Brasil. Revista Turismo. [serial on the Internet]. 2008 Nov [cited 2008 Nov 19]. Available from: http://www.revistaturismo.com.br/artigos/crescimentobrasil.html.

Katz N 1998. Schistosomiasis control in Brazil. Mem Inst Oswaldo Cruz 93 (Suppl. I): 33-35.

Katz N, Chaves A, Pellegrino J 1972. A simple device for quantitative stool thick-smear technique in schistosomiasis mansoni. Rev Inst Med Trop Sao Paulo 14: 397-400.

Katz N, Peixoto SV 2000. Análise crítica da estimativa do número de portadores de esquistossomose mansoni no Brasil. Rev Soc Bras Med Trop 33: 303-308.

Massara CL, Amaral GL, Caldeira RL, Drummond SC, Enk MJ, Carvalho $\mathrm{O}$ dos S 2008. Esquistossomose em área de ecoturismo do estado de Minas Gerais, Brasil. Cad Saude Publica 24: 1709-1712.

Paraense WL 1975. Estado atual da sistemática dos planorbídeos brasileiros. Arq Mus Nac 55: 105-111.

Tomé CM, Cipolli E, Coelho da Silva CLPA, Borges DA, Soares MS 2003. Esquistossomose na estância turística de Holambra (SP, Brasil). In Anais do $9^{\circ}$ Simpósio Internacional sobre Esquistossomose, Belo Horizonte: Programa Integrado de Esquistossomose, Fundação Oswaldo Cruz, p. 68.

Vidigal TH, Spatz L, Nunes ND, Simpson AJG, Carvalho OS, Dias Neto E 1998. Biomphalaria spp: identification of the intermediate snail host of Schistosoma mansoni by polymerase chain reaction amplification and restriction enzyme digestion of the ribosomal RNA gene intergenic spacer. Exp Parasitol 89: 180-187. 